\title{
STIGMA SOSIAL PADA KELUARGA PASIEN CORONA VIRUS DISEASE 2019 DI KECAMATAN SUNGAILIAT KABUPATEN BANGKA
}

\author{
Firginia Elviera ${ }^{1,}$ Putra Pratama Saputra ${ }^{2}$, Amir Dedoe $^{3}$ \\ 1)2)3) Universitas Bangka Belitung \\ firginiaelviera@gmail.com
}

$\underline{\text { Received : } 3 \text { July 202| Reviewed: } 26 \text { July } 2021 \mid \text { Accepted: } 24 \text { August } 2021}$

\begin{abstract}
ABSTRAK
Penelitian ini mengenai stigma yang muncul dalam masyarakat Kecamatan Sungailiat Kabupaten Bangka yang ditujukan kepada keluarga pasien Coronavirus Disease 2019 yang belum tentu terinfeksi tetapi tetap mendapatkan stigma negatif dari masyarakat. Penelitian ini bertujuan untuk menggambarkan bentuk stigma sosial dan cara keluarga pasien Coronavirus Disease 2019 mengelola stigma yang diberikan masyarakat Kecamatan Sungailiat. Metode penelitian yang digunakan adalah metode kualitatif dengan jenis penelitian deskriptif. Data dikumpulkan melalui wawancara, observasi, dan studi kepustakaan. Peneliti menemukan bahwa masyarakat memberikan stigma kepada keluarga pasien Coronavirus Disease 2019 dengan pembatasan kontak sosial berupa perilaku mengucilkan, mengasingkan, menjauhi, dan menghindar yang disebabkan karena adanya rasa takut, waspada, dan kurangnya kerahasiaan dalam masyarakat. Keluarga pasien Coronavirus Disease 2019 melakukan pengelolaan stigma yaitu menuruti keinginan masyarakat untuk menjaga jarak dengan mereka serta tetap melakukan interaksi dengan masyarakat sekitar agarterlihat normal.
\end{abstract}

Kata Kunci: Coronavirus Disease 2019, Keluarga Pasien, Stigma Sosial

Korespondensi:

Universitas Bangka Belitung

Jl. Kampus Terpadu UBB, Kel. Balunijuk, Kec.

Merawang, Kabupaten Bangka, Kepulauan Bangka

Belitung.

JURNAL ILMIAH DINAMIKA SOSIAL 5 (1) 2021 | 135

E-mail: firginiaelviera@gmail.com 


\begin{abstract}
This research is about the stigma that appears in Sungailiat District, Bangka Regency which is aimed at the families of Coronavirus Disease 2019 patients who are not necessarily infected but still getnegative stigma from the community. This study aims to describe the form of social stigma and the way families of Coronavirus Disease 2019 patients manage the stigma given by the community of Sungailiat District. The research method used is a qualitative descriptive research type. The data was collected from observation, interviews, and literature study. Researchers found that society stigmatizes families of Coronavirus Disease 2019 patients by limiting social contact in the form of isolating, alienating, and avoiding caused by fear, vigilance, and lack of confidentiality in society. The families of Coronavirus Disease 2019 managing stig ma namely following the wishes of the community to keep their distance from them and continuing to interact with the surrounding community to make it look normal.
\end{abstract}

Keywords: Coronavirus Disease 2019, Patients Family, Social Stigma

\title{
PENDAHULUAN
}

Stigmatisasi terhadap suatu penyakit merupakan suatu hal yang tidak bisa dikontrol didalam masyarakat terutama pada penyakit yang dapat menular. Stigmatisasi adalah asumsi negatif terhadap individu lain yang dianggap memiliki perbedaan dalam dirinya. Individu yang mendapat stigma dibuat untuk memiliki beberapa atribut atau karakteristik yang mengandung identitas sosial (Sarwono, 2018). Stigma sosial terbentuk dari adanya prasangka masyarakat terhadap individu yang mengandung suatu identitas. Goffman (Santoso, 2016) mengemukakan bahwa stigma adalah segala bentuk atribut fisik dan sosial yang mengurangi identitas seseorang serta mendiskualifikasikan orang tersebut dari penerimaan seseorang.

Penyakit yang sifatnya menular akan menimbulkan stigma dalam masyarakat. Individu yang terlibat didalamnya tidak bisa melarikan diri dari stigma yang diberikan masyarakat karena cirinya nyata terlihat. Stigma pada penyakit ini biasanya ditujukan pada penyakit seperti HIV AIDS dan penyakit-penyakit lain yang sifatnya menular seperti yang terjadi saat ini, stigma sosial ditujukan kepada Coronavirus Disease 2019. Stigma sosial merupakan salah satu dampak dari adanya pandemi virus Corona.

Kehidupan masyarakat menjadi berubah seiring dengan adanya pandemi. Pandemi telah menyebabkan terjadinya perubahan sosial. Menurut Sztompka, perubahan sosial berbicara tentang sesuatu hal terjadi dalam jangka waktu tertentu yang berurusan dengan perbedaan keadaan yang diamati antara belum dan sesudah jangka waktu tertentu 
(Martono, 2012). Stigma sosial disebabkan karena adanya perubahan pada perilaku sosial masyarakat. Perubahan perilaku sosial masyarakat ini berupa perilaku hidup sehat seperti menjaga jarak, memakai masker, dan mencuci tangan. Selain itu, pandemi juga menyebabkan perubahan pandangan individu terhadap orang lain.

Stigma yang ada didalam masyarakat menimbulkan prasangka dan diskriminasi terhadap orang-orang yang terlibat didalam Coronavirus Disease 2019 seperti orangorang yang terlibat dalam kasus kontak erat, kasus suspek, kasus konfirmasi tanpa gejala, dan kasus terkonfirmasi. Prasangka jika ditunjukkan pada sebuah tindakan, maka bentuknya dapat berupa diskriminasi, gejala, dan peristiwa yang bercorak pada tindakantindakan diskriminatif (Hanurawan, 2019).

Selain ditujukan pada pasien Coronavirus Disease 2019, stigma juga ditujukan kepada keluarga mereka seperti yang terjadi di Kepulauan Bangka Belitung tepatnya di Kecamatan Sungailiat, Kabupaten Bangka. Kecamatan Sungailiat merupakan salah satu wilayah zona merah di Kepulauan Bangka Belitung yang menduduki posisi pertama sebagai wilayah dengan kasus Coronavirus Disease 2019 terbanyak. Berikut merupakan tabel jumlah kasus Coronavirus Disease 2019 di Kecamatan Sungailiat Kabupaten Bangka.

\section{Tabel 1}

Jumlah Kasus Coronavirus Disease 2019 Kecamatan Sungailiat Kabupaten Bangka Tanggal 01 Juli 2021.

\begin{tabular}{|c|l|c|}
\hline No & $\begin{array}{c}\text { Status dalam Coronavirus } \\
\text { Disease 2019 }\end{array}$ & Jumlah (Orang) \\
\hline 1 & Kasus Terkonfirmasi & 2.067 \\
\hline 2 & Kasus Sembuh & 1.960 \\
\hline 3 & Kasus Suspek & 1.270 \\
\hline 4 & Kasus Kontak Erat & 2.012 \\
\hline
\end{tabular}

Sumber: Dinas Kesehatan Kabupaten Bangka 2021.

Kasus Coronavirus Disease 2019 di Kecamatan Sungailiat terus bertambah secara signifikan. Berdasarkan hasil survey awal yang telah dilakukan oleh peneliti di beberapa wilayah kelurahan yang ada di Kecamatan Sungailiat Kabupaten Bangka, didapatkan 
informasi bahwa para keluarga pasien Coronavirus Disease 2019 mendapat perlakuan yang tidak menyenangkan seperti diasingkan, dikucilkan, dan yang paling parah sampai pada pengusiran. Pengusiran ini terjadi di Lingkungan Air Kantung Kelurahan Sungailiat. Masyarakat menolak kehadiran salah satu keluarga pasien Coronavirus Disease 2019 yang ingin menyewa rumah kontrakan untuk isolasi mandiri.

Penolakan yang masyarakat lakukan seperti di Lingkungan Air Kantung Kelurahan Sungailiat terhadap keluarga pasien Coronavirus Disease 2019 disebabkan oleh adanya prasangka yang menimbulkan perbedaan antara asumsi masyarakat dengan kondisi yang sebenarnya. Dengan adanya stigma sosial yang ditujukan kepada keluarga pasien Coronavirus Disease 2019 di Kecamatan Sungailiat Kabupaten Bangka ini, peneliti merasa tertarik untuk mengkaji fenomena sosial tersebut karena keluarga pasien Coronavirus Disease 2019 belum tentu terinfeksi tetapi tetap mend apatkan stigma negatif dari masyarakat dengan mengidentifikasi bentuk stigma sosial yang ditujukan kepada keluarga pasien Coronavirus Disease 2019 serta cara mereka mengelola stigma yang diberikan masyarakat Kecamatan Sungailiat sehingga dapat diketahui bahwa stigma sosial ini dapat menjadikan keluarga pasien Coronavirus Disease 2019 semakin termarjinalkan.

Selain itu, penelitian mengenai stigma sosial terhadap keluarga pasien Coronavirus Disease 2019 jarang ditemui oleh peneliti dan masalah mengenai stigma sosial yang ditujukan kepada orang-orang yang terlibat didalam Coronavirus Disease 2019 ini terbilang masih baru sejak di temukannya virus Corona tahun 2019. Peneliti juga ingin melihat perbedaan stigma yang dialami oleh keluarga pasien Coronavirus Disease 2019 di Kecamatan Sungailiat dengan wilayah Indonesia lainnya. Permasalahan mengenai stigma sosial yang ditujukan kepada keluarga pasien Coronavirus Disease 2019 di Kecamatan Sungailiat Kabupaten Bangka ini akan menggunakan teori Stigma dari Erving Goffman sebagai pisau analisis.

\section{KAJIAN TEORI}

Dalam penelitian ini, peneliti akan menggunakan teori stigma dari Erving Goffman untuk menganalisis masalah penelitian. Teori ini dianggap relevan untuk mengkaji masalah penelitian tentang konsep Stigma Sosial pada Keluarga Pasien Coronavirus Disease 2019 di Kecamatan Sungailiat Kabupaten Bangka. Dalam ilmu sosiologi, nama 
Erving Goffman sudah tidak asing lagi. Beliau merupakan tokoh sosiologi dengan pemikiran terkenalnya mengenai dramaturgi. Erving Goffman merupakan salah satu tokoh sosiologi yang pemikirannya dipengaruhi oleh George Herbert Mead yang merupakan tokoh sosiologi dalam teori interaksionisme simbolik (Susanto, 2016).

Goffman melakukan kajian terhadap stigma sosial. Menurut Goffman (Ardianti, 2017), stigma merupakan tanda atau tanda yang dibuat oleh tubuh seseorang yang dibuat oleh tubuh seseorang untuk diperlihatkan dan menginformasikan kepada masyarakat bahwa orang-orang yang mempunyai tanda tersebut merupakan seorang budak, kriminal, atau seorang pengkhianat, serta suatu ungkapan atas ketid akwajaran dan keburukan status moral yang dimiliki oleh seseorang.

Dalam teori stigma, Erving Goffman menjelaskan beberapa konsep. Menurut Beliau, individu membentuk identitas dari proses interaksi dengan masyarakat. Erving Goffman (Mahmudah, 2011) membagi identitas individu menurut setting sosialnya menjadi dua, yaitu virtual social identity dan actual social identity. Menurut Goffman (Mahmudah, 2011), virtual social identity merupakan identitas yang terbentuk dari asumsi atau pikiran orang-orang terhadap individu dalam masyarakat. Sedangkan actual social identity merupakan identitas yang terbentuk dari karakter-karakter yang telah terbukti. Setiap individu yang ada didalam masyarakat memiliki perbedaan dalam dua identitas tersebut. Apabila perbedaan tersebut diketahui oleh orang lain atau masyarakat, maka individu tersebut akan diberi stigma dan dikucilkan.

Teori stigma Erving Goffman tidak lepas dari interaksi dramaturgi antara penerima dengan pemberi stigma. Goffman (Novanto, 2017) menyatakan bahwa dalam kasus stigma, terdapat dua bentuk yaitu discredit stigma dan discreditable stigma. Discredit stigma adalah perbedaan antara orang normal dengan orang yang diberi stigma atau dianggap menyimpang yang diketahui. Sedangkan discreditable stigma adalah perbed aan antara orang normal dengan orang yang diberikan stigma yang tidak diketahui. Dramaturgis erat kaitannya dengan discreditable stigma karena orang yang diberi stigma akan melakukan pengelolaan terhadap dirinya agar tetap terlihat normal. Sedangkan pada discredit stigma, seseorang yang telah terstigma melakukan pengelolaan dengan berperilaku tidak lebih buruk dari apa yang telah terjadi. Adapun kerangka berpikir yang telah dirumuskan, yaitu: 


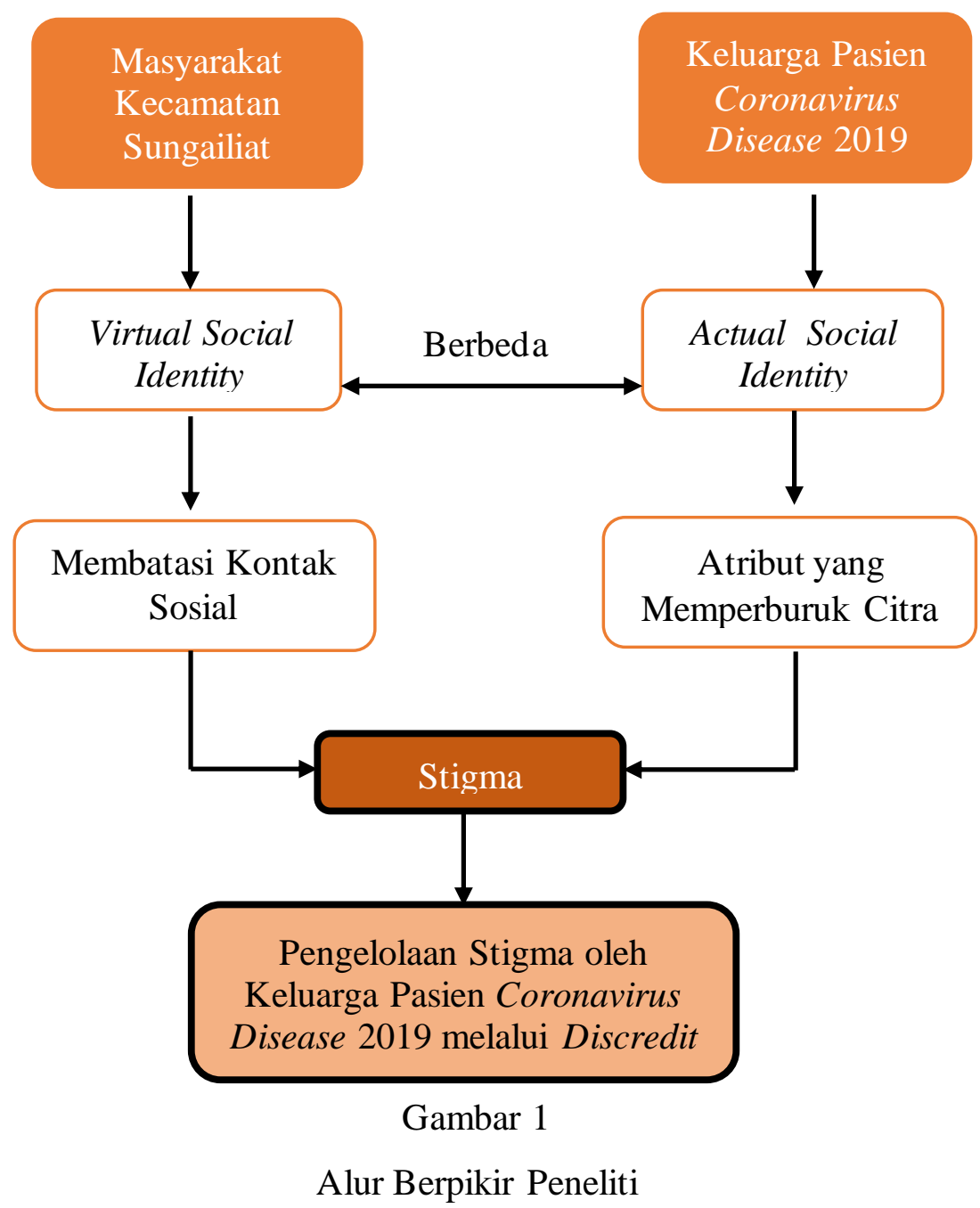

Dari gambar alur berpikir diatas dapat dijelaskan bahwa keluarga pasien Coronavirus Disease 2019 mendapat stigma dari masyarakat umum atau masyarakat Kecamatan Sungailiat karena adanya perbedaan antara asumsi (Virtual Social Identity) dengan kenyataan (Actual Social Identity). Setiap individu yang ada didalam masyarakat memiliki perbedaan dalam dua identitas tersebut. Apabila perbedaan tersebut diketahui oleh orang lain atau masyarakat, maka individu tersebut akan diberi stigma dan dikucilkan (Falidah, 2020) .

Stigma muncul seiring dengan terjadinya pandemi di Indonesia. Stigma akan terjadi didalam masyarakat yang didalamnya terdapat orang-orang yang terlibat didalam Coronavirus Disease 2019. Salah satu zona merah yang ad a di Indonesia adalah Provinsi Kepulauan Bangka Belitung tepatnya di Kecamatan Sungailiat Kabupaten Bangka. Wilayah ini merupakan wilayah yang menempati urutan pertama sebagai daerah yang memiliki kasus terkonfirmasi terbanyak. Selain stigma pada orang dalam kasus 
terkonfirmasi, stigma juga ditujukan pada keluarga pasien Coronavirus Disease 2019. Analisis permasalahan penelitian berdasarkan pada teori stigma dari Erving Goffman terdiri dari konsep identity dan discredit.

Goffman (Varamitha et al., 2014) mengemukakan konsep the normals dan the stigmatize. Istilah the normals ditujukan pada orang-orang yang tidak terkena stigma. Orang-orang normal menganggap bahwa orang-orang yang terkena stigma bukan merupakan orang yang normal. Dalam the stigmatized, orang yang diberi stigma berpikir bahwa mereka merupakan orang normal seperti orang lain, akan tetapi orang lain belum siap menerima dan menganggap mereka sama. Orang yang diberi stigma, akan merespon situasi yang dialaminya tersebut dengan mengevalusi apa yang ad a didalam dirinya yang menjadi penyebab munculnya stigma. Penelitian ini akan menggunakan teori stigma dari Erving Goffman untuk membedah masalah yang akan dikaji melalui konsep identity dan discredit.

\section{METODE PENELITIAN}

Penelitian ini merupakan jenis penelitian kualitatif dengan pendekatan analisis deskriptif. Menurut Bogdan dan Taylor (Afrizal, 2016), penelitian kualitatif adalah prosedur penelitian yang menghasilkan data deskriptif berupa kata-kata tertulis atau lisan dari orang-orang dan perilaku yang diamati. Dalam penelitian ini, peneliti akan melakukan pencarian fakta yang ada didalam masyarakat Kecamatan Sungailiat Kabupaten Bangka terkait stigma sosial yang ditujukan pada pasien Coronavirus Disease 2019 dan keluarganya. Dalam hal ini, peneliti menggunakan metode ini karena dianggap relevan dalam menelusuri konsep stigma sosial pada keluarga pasien Coronavirus Disease 2019 yang dikaitkan dengan teori stigma dari Erving Goffman. Penelitian kualitatif dianggap relevan oleh peneliti karena peneliti membutuhkan pendalaman data deskriptif secara langsung terkait konsep stigma sosial pada keluarga pasien Coronavirus Disease 2019 yang ada didalam masyarakat Kecamatan Sungailiat Kabupaten Bangka. Pendekatan analisis deskriptif kemudian menjadi relevan dalam penelitian ini karena berkaitan dengan rumusan masalah.

Penelitian ini dilakukan di Kecamatan Sungailiat Kabupaten Bangka. Kecamatan Sungailiat terdiri dari 12 Kelurahan dan 1 desa yaitu Kelurahan Kenanga, Kelurahan Parit Padang, Kelurahan Srimenanti, Kelurahan Sungaliat, Kelurahan Kuday, Kelurahan Sinar 
Baru, Kelurahan Lubuk Kelik, Kelurahan Surya Timur, Kelurahan Jelitik, Kelurahan Bukit Betung, Kelurahan Sinar Jaya Jelutung, Kelurahan Matras, dan Desa Rebo. Alasan dipilihnya lokasi tersebut karena lokasi ini merupakan zona merah Coronavirus Disease 2019 di Provinsi Kepulauan Bangka Belitung dengan menduduki posisi pertama sebagai daerah dengan jumlah kasus terkonfirmasi terbanyak.

Selain itu, di Kelurahan Air Kantung, Kecamatan Sungailiat pernah terjadi pengusiran terhadap salah satu pekerja perusahaan swasta dan anaknya yang akan menyewa rumah kontrakan untuk isolasi mandiri. Masyarakat disana menolak kehadiran pekerja dan anaknya tersebut. Peneliti merasa tertarik untuk melihat stigma sosial yang ada di Kecamatan Sungailiat karena jika dibandingkan dengan wilayah di Indonesia lainnya tingkat stigma yang ada di Kecamatan Sungailiat tidak separah stigma sosial yang ada di wilayah Indonesia lainnya.

Sumber data dalam penelitian ini yaitu sumber data primer berupa hasil wawancara yang mendalam dengan masyarakat dan keluarga pasien Coronavirus Disease 2019 di Kecamatan Sungailiat Kabupaten Bangka mengenai stigma sosial serta sumber data sekunder yang didapatkan melalui buku referensi, artikel, website, berita, jurnal penelitian, dan skripsi dari penelitian terdahulu yang dianggap relevan dengan penelitian ini. Dalam penelitian ini, peneliti menentukan informan dengan cara purposive sampling dan accidental sampling. Kriteria informan dalam penelitian ini adalah informan yang berjenis kelamin laki-laki maupun perempuan khususnya informan yang memiliki rumah tidak jauh dari tempat keluarga pasien Coronavirus Disease 2019 tinggal karena hal tersebut menandakan orang-orang tersebut memiliki interaksi yang sering dengan keluarga pasien Coronavirus Disease 2019 di Kecamatan Sungailiat. Selain itu dengan teknik purposive sampling ini, peneliti lebih menekankan pada kualitas bukan kuantitas informan. Kegiatan penelitian akan diberhentikan apabila peneliti telah menemukan titik jenuh atau kesamaan jawaban wawancara dari informan.

Dalam penelitian ini, yang menjadi subjek penelitian adalah masyarakat Kecamatan Sungailiat Kabupaten Bangka yang tinggal di sekitar pasien Coronavirus Disease 2019 dan keluarganya. Alasannya karena masyarakat yang tinggal di sekitar pasien Coronavirus Disease 2019 dan keluarganya yang sering berinteraksi dengan mereka. Informan lainnya yaitu keluarga Pasien Coronavirus Disease 2019 yang merupakan kerabat dekat dari pasien yang terinfeksi atau orang terdekat yang berinteraksi 
secara langsung dengan anggota keluarga lain yang terinfeksi Coronavirus Disease 2019. Dalam hal ini, stigma sosial ditujukan kepada individu yang terlibat didalam Coronavirus Disease 2019 yaitu individu yang terinfeksi beserta keluarganya yang tinggal di Kecmatan Sungailiat Kabupaten Bangka. Informan yang dipilih sesuai dengan kriteria peneliti yaitu masyarakat Kecamatan Sungailiat yang sering berinteraksi dengan keluarga pasien Coronavirus Disease 2019 dan didapatkan sebanyak 14 orang informan yaitu 6 orang keluarga pasien Coronavirus Disease 2019 dan 8 orang masyarakat umum. Berikut merupakan tabel informan penelitian.

Tabel 2

Informan Penelitian

\begin{tabular}{|c|l|c|c|}
\hline No & Nama & Jenis Kelamin & Pekerjaan \\
\hline 1 & YT & Perempuan & Wirausaha \\
\hline 2 & JL & Perempuan & Mahasiswi \\
\hline 3 & NB & Perempuan & Pelajar \\
\hline 4 & KU & Laki-laki & Wiraswasta \\
\hline 5 & MN & Perempuan & Ibu Rumah Tangga \\
\hline 6 & AF & Perempuan & Ibu Rumah Tangga \\
\hline 7 & AN & Perempuan & Wirausaha \\
\hline 8 & DS & Perempuan & Ibu Rumah Tangga \\
\hline 9 & DR & Perempuan & Buruh Harian \\
\hline 10 & SR & Laki-laki & PNS \\
\hline 11 & SH & Laki-laki & Buruh Harian \\
\hline 12 & OI & Perempuan & Mahasiswi \\
\hline 13 & SY & Perempuan & Pedagang \\
\hline 14 & TI & Suana & \\
\hline
\end{tabular}

Sumber: Hasil Pengolahan Data Peneliti Tahun 2021.

Pengumpulan data dilakukan melalui wawancara, observasi, dan dokumentasi dengan mengamati, mencatat, serta merekam aktivitas-aktivitas yang berkaitan dengan stigma sosial yang ditujukan kepada keluarga pasien Coronavirus Disease 2019 di Kecamatan Sungailiat Kabupaten Bangka. Teknik analisis data yang digunakan adalah teknik analisis data Creswell. Berikut langkah-langkah dalam analisis Cresswell.

1. Mengorganisasikan dan menyiapkan data yang akan dianalisis 
Data mentah yang didapatkan di lapangan mengenai stigma sosial padakeluarga pasien Coronavirus Disease 2019 di Kecamatan Sungailiat akan dianalisis dan diorganisasikan berdasarkan sumber data, jenis data, deskripsi data, dan sifat data.

2. Baca dan lihat seluruh data

Peneliti membaca seluruh data mengenai stigma sosial pada keluarga pasien Coronavirus Disease 2019 Coronavirus Disease 2019 di Kecamatan Sungailiat agar dapat mengetahui data apa saja yang diperoleh, sumber data, dan maknanya. Peneliti harus mengetahui keluarga pasien Coronavirus Disease 2019 menyampaikan informasi apa saja, lalu bandingkan dengan informan lain.

3. Membuat koding seluruh data

Koding adalah proses pemberian tanda terhadap data yang telah dikelompokkan. Kelompok data yang sejenis diberi kode yang sama. Proses pemberian kode dapat dilakukan secara manual atau melalui komputer. Data yang sama mengenai stigma sosial pada keluarga pasien Coronavirus Disease 2019 di Kecamatan Sungailiat akan dikelompokkan dan diberi kode secara manual maupun melalui komputer.

4. Menggunakan koding sebagai bahan untuk membuat deskripsi

Melalui koding, penelitian mengenai stigma sosial pada keluarga pasien Coronavirus Disease 2019 di Kecamatan Sungailiat ini akan menghasilkan tematema atau kategorisasi data penelitian. Berdasarkan tema-tema yang dihasilkan, selanjutnya peneliti membuat deskripsi secara singkat dan sistematis sehingga tematema yang ditemukan menjadi lebih jelas.

5. Menghubungkan antar tema

Peneliti membuat kategori data mengenai stigma sosial pada keluarga pasien Coronavirus Disease 2019 di Kecamatan Sungailiat yang telah didapatkan dilapangan. Kemudian disusun dalam tema-tema penelitian, maka selanjutnya adalah mencari hubungan antar tema satu dengan yang lain.

6. Memberi interpretasi dan makna tentang tema

Hasil kontruksi hubungan antara tema atau kategori dari data yang telah diolah mengenai stigma sosial pada keluarga pasien Coronavirus Disease 2019 di Kecamatan Sungailiat, selanjutnya perlu diberikan interpretasi sehingga orang lain memahaminya. 


\section{PEMBAHASAN}

Faktor Penyebab Munculnya Stigma pada Keluarga Pasien Coronavirus Disease 2019 di Kecamatan Sungailiat, Kabupaten Bangka

Dengan kemunculan individu yang terinfeksi virus Corona di tengah-tengah masyarakat menimbulkan berbagai reaksi dari masyarakat. Reaksi masyarakat terhadap keberadaan Coronavirus Disease 2019 menyebabkan munculnya berbagai stigma. Reaksi yang ditimbulkan masyarakat ini berupa rasa takut dengan keberadaan pasien Coronavirus Disease 2019 dan keluarganya. Coronavirus Disease 2019 yang dapat menyebabkan kematian bagi penderitanya menyebabkan masyarakat menjadi takut berhadapan dengan keluarga pasien Coronavirus Disease 2019 walaupun hasil tes nihil karena dianggap masih dapat menularkan penyakit ini. seperti yang dikatan oleh Bapak DR yang masih takut berhadapan dengan keluarga pasien Coronavirus Disease 2019 karena dianggap masih bisa menularkan virus Corona. Agar masyarakat lainnya juga terhindar dari hal-hal yang tidak diinginkan, maka Beliau menginformasikan kepada masyarakat lainnya agar mereka menghimbau anak-anak mereka agar menghindar dengan tidak bermain di sekitar tempat tinggal keluarga pasien Coronavirus Disease 2019.

Masyarakat takut dan khawatir dengan adanya keberadaan pasien Coronavirus Disease 2019 dan keluarganya di sekitar kita karena takut terinfeksi virus Corona sebab dampak yang ditimbulkan adalah kita akan dijauhi oleh masyarakat sekitar jika salah satu keluarga kita terinfeksi Coronavirus Disease 2019. Waspada menjadi faktor selanjutnya sebagai penyebab munculnya stigma dalam masyarakat. Hal ini disampaikan oleh Bapak OI, Beliau takut dan khawatir dengan adanya keberadaan pasien Coronavirus Disease 2019 dan keluarganya di sekitar Beliau karena takut terinfeksi virus Corona sebab dampak yang ditimbulkan adalah kita akan dijauhi oleh masyarakat sekitar jika salah satu keluarga kita terinfeksi Coronavirus Disease 2019. Tindakan waspada pada keberadaan pasien Coronavirus Disease 2019 dan keluarganya di dekat tempat tinggal membuat masyarakat menghindar dengan membatasi kontak sosial dan lebih menerapkan protokol kesehatan. Sikap waspada masyarakat ini dilakukan agar terhindar dari virus Corona karena virus tersebut mudah menyerang siapapun. 
Selain itu, individu yang terinfeksi penyakit ini ada yang gejalanya tidak nampak sehingga waspada diperlukan. Kurangnya kerahasiaan seperti adanya kunjungan dari petugas kesehatan yang menggunakan atribut pelindung diri lengkap serta mobil dengan logo Coronavirus Disease 2019 secara terang-terangan dapat menyinggung pribadi keluarga pasien Coronavirus Disease 2019 karena adanya pengungkapan identitas yang tidak di inginkan. Kurangnya kerahasiaan seperti penjemputan pasien Coronavirus Disease 2019 secara terang-terangan ini berdampak pada identitas sosial keluarga pasien Coronavirus Disease 2019.

Dengan adanya kunjungan oleh petugas kesehatan dengan atribut lengkap secara terang-terangan menyebabkan masyarakat mengetahui identitas keluarga pasien Coronavirus Disease 2019. Saat petugas datang, masyarakat langsung mencari tahu dan masyarakat pun menjadi tidak berani mendekati mereka. Selain itu, petugas kesehatan juga datang berserta polisi dan Satpol Pamong Praja sehingga membuat pengungkapan identitas keluarga pasien Coronavirus Disease 2019 tersebut terlihat mencolok. Berikut merupakan tabel dari faktor penyebab munculnya stigma:

Tabel 3

Faktor Penyebab Munculnya Stigma Pada Keluarga Pasien Coronavirus Disease 2019 di Kecamatan Sungailiat Kabupaten Bangka

\begin{tabular}{|c|c|c|}
\hline No. & Faktor-faktor & Uraian \\
\hline 1 & Takut & $\begin{array}{l}\text { Takut terinfeksi virus Corona sebab } \\
\text { dampak yang ditimbulkan adalah } \\
\text { akan dijauhi oleh masyarakat } \\
\text { sekitar jika salah satu anggota } \\
\text { keluarga terinfeksi Coronavirus } \\
\text { Disease } 2019 \text {. }\end{array}$ \\
\hline 2 & Waspada & $\begin{array}{l}\text { Masyarakat menerapkan sikap } \\
\text { waspada kepada keluarga pasien } \\
\text { Coronavirus Disease } 2019 \text { agar } \\
\text { tidak terjangkit dari virus Corona } \\
\text { karena penyakit ini tidak kasat mata } \\
\text { sehingga yang awalnya individu }\end{array}$ \\
\hline
\end{tabular}




\begin{tabular}{|l|l|l|}
\hline 3 & $\begin{array}{l}\text { tidak terinfeksi dapat tiba-tiba } \\
\text { terinfeksi Coronavirus Disease } \\
2019 .\end{array}$ \\
\hline Kurangnya Kerahasiaan & $\begin{array}{l}\text { Kunjungan petugas kesehatan yang } \\
\text { memakai alat pelindung diri di } \\
\text { kendaraan yang ditandai dengan } \\
\text { logo tulisan Coronavirus Disease } \\
2019 \text { dapat menyinggung pribadi } \\
\text { keluarga pasien Coronavirus } \\
\text { Disease 2019 karena adanya } \\
\text { pengungkapan identitas yang tidak } \\
\text { di inginkan yaitu memberikan tanda } \\
\text { atau atribut yang menginformasikan } \\
\text { kepada masyarakat bahwa keluarga } \\
\text { pasien keluarga pasien Coronavirus } \\
\text { Disease 2019 memiliki atribut yang } \\
\text { tidak biasa. }\end{array}$ \\
\hline
\end{tabular}

Sumber: Hasil Pengolahan Data Peneliti Tahun 2021.

Dengan adanya penjemputan oleh petugas kesehatan dengan atribut lengkap secara terang-terangan menyebabkan masyarakat mengetahui identitas keluarga pasien Coronavirus Disease 2019. Saat petugas datang, masyarakat langsung mencari tahu dan masyarakat pun menjadi tidak berani mendekati mereka. Selain itu, petugas kesehatan juga datang berserta polisi dan Satpol Pamong Praja sehingga membuat pengungkapan identitas keluarga pasien Coronavirus Disease 2019 tersebut terlihat mencolok. Pasien Coronavirus Disease 2019 dan keluarganya merasa tidak enak hati kepada masyarakat jika tempat tinggal mereka didatangi oleh petugas kesehatan. Hal ini dikarenakan pasien Coronavirus Disease 2019 dan keluarganya khawatir dengan reaksi masyarakat terhadap mereka sehingga memilih pergi sendiri ke tempat karantina.

Di Kecamatan Sungailiat, masyarakat memberikan asumsi atau stigma berupa pembedaan diri dikarenakan masyarakat mengetahui adanya perbedaan antara 
masyarakat dengan keluarga pasien Coronavirus Disease 2019 yaitu atribut yang dibuat di dalam tubuh mereka melalui pengungkapan identitas yang tidak di inginkan seperti datangnya petugas kesehatan dengan logo Coronavirus Disease 2019 secara terangterangan ke rumah keluarga pasien Coronavirus Disease 2019. Seperti yang dikatakan oleh Goffman bahwa seseorang yang diberikan stigma karena adanya atribut yang mengarah pada identitas sosial seseorang yang akan menginformasikan kepada masyarakat bahwa individu tersebut memiliki tanda. Tanda disini berupa penjemputan secara terang-terangan yang dilakukan oleh petugas kesehatan. Selain itu, adanya rasa takut dan waspada terhadap keluarga pasien Coronavirus Disease 2019 juga menjadi penyebab dari munculnya stigma dalam masyarakat.

\section{Bentuk Stigma Sosial Pada Keluarga Pasien Coronavirus Disease 2019 Di Kecamatan Sungailiat}

Pemikiran dan reaksi negatif masyarakat terhadap pasien Coronavirus Disease 2019 dan keluarganya di Kecamatan Sungailiat disebabkan oleh adanya atribut yang mengarah pada identitas sosial seperti kurangnya kerahasiaan dengan melakukan penjemputan pasien Coronavirus Disease 2019 secara terang-terangan telah menimbulkan stigma masyarakat terhadap pasien yang terinfeksi juga pada keluarganya. Selain itu, stigma juga muncul karena kurangnya edukasi masyarakat mengenai virus Corona. Stigma muncul dari adanya prasangka. Prasangka jika diwujudkan dalam bentuk sikap maka berupa stigma yang cenderung bersikap negatif dan ke arah psikologis. Sedangkan, prasangka jika diwujudkan dalam suatu tindakan berupa diskriminasi dan peristiwa-peristiwa yang cenderung pada tindakan-tindakan diskriminasi. Stigma pada sebuah penyakit merupakan salah satu bentuk stigma yang tidak dapat dikontrol oleh masyarakat.

Bentuk stigma yang diberikan masyarakat pada keluarga pasien Coronavirus Disease 2019 ini telah mengarah pada tindakan diskriminatif. Dalam hal ini, tindakan diskriminatif telah menjadi tahap akhir atau puncak dari pemberian stigma oleh masyarakat. Adanya diskriminasi tercermin dari perilaku masyarakat terhadap keluarga pasien Coronavirus Disease 2019. Bentuk perilaku tersebut antara lain mengucilkan, mengasingkan, menghindar, menjauhi, dan membatasi interaksi kepada keluarga pasien Coronavirus Disease 2019 walaupun surat keterangan dokter menunjukkan hasil negatif. 
Keluarga pasien Coronavirus Disease 2019 merasa dikucilkan dan diasingkan oleh masyarakat sekitar tempat tinggalnya. Masyarakat seperti ketakutan dengan adanya individu yang terinfeksi di dalam lingkungan tempat tinggalnya. Ibu YT selaku keluarga salah satu pasien Coronavirus Disease 2019 menyatakan bahwa Beliau merasa dikucilkan. Masyarakat takut dengan keberadaan mereka. Saat berjualan, tidak ada satupun masyarakat yang membeli dagangan dari Ibu YT. Adapula masyarakat yang datang membeli dagangan dari Ibu YT yang sudah memakai masker namun di tutup lagi menggunakan hijab. Anak dari Ibu YT juga tak luput dari stigma masyarakat. Tetangga Beliau tidak mengizinkan anaknya bermain dengan anak Ibu YT. Hal ini membuat Ibu YT merasa sedih dan kecewa.

Hal yang sama juga dirasakan oleh Saudari JL selaku keluarga pasien Coronavirus Disease 2019. Masyarakat memberikan reaksi yang sinis kepada Saudari JL selaku keluarga pasien Coronavirus Disease 2019. Beliau merasa dikucilkan yang membuat perasaan beliau sedih. Masyarakat merasa was-was dengan keberadaan Saudari JL dan anggota keluarganya yang lain. Selain itu, teman-teman Beliau juga belum ingin bertemu dengan Saudari JL walaupun surat keterangan dokter sudah beliau lampirkan bahwa beliau negatif Coronavirus Disease 2019. Dengan adanya perilaku masyarakat seperti ini membuat keluarga pasien Coronavirus Disease 2019 kesulitan untuk mendapatkan kebebasan dalam melakukan aktivitas sehari-sehari seperti sulit berinteraksi dengan masyarakat sekitar dan juga menyembunyikan identitas keluarganya yang terinfeks. Masyarakat seperti ketakutan dengan adanya individu yang terinfeksi di dalam lingkungan tempat tinggalnya.

Munculnya berbagai reaksi masyarakat terhadap pasien Coronavirus Disease 2019 dan keluarganya di Kecamatan Sungailiat telah menyebabkan munculnya berbagai bentuk stigma yang mengarah pada tindakan diskriminasi dengan membatasi interaksi seperti pengasingan, pengucilan, menghindar dan menjauhi keluarga pasien Coronavirus Disease 2019. Masyarakat memberikan stigma negatif kepada keluarga pasien Coronavirus Disease 2019 karena adanya atribut yang tidak biasa didalam diri mereka. Dalam hal ini, masyarakat yang berperan dan bertindak sebagai the normals yaitu orang yang normal yang ditujukan pada orang-orang yang tidak terkena stigma. Menurut Goffman, orang-orang normal atau the normals akan menganggap bahwa orang-orang yang terkena stigma bukan bagian dari orang normal. Namun, the stigmatized atau orang- 
orang yang terkena stigma akan menganggap diri mereka sebagai orang normal sama dengan orang lainnya.

Di Kecamatan Sungailiat, masyarakat menganggap keluarga pasien Coronavirus Disease 2019 berbeda karena status yang melekat pada diri mereka. Keluarga pasien Coronavirus Disease 2019 menganggap diri mereka sama seperti masyarakat lainnya dengan berperilaku seperti biasa dalam menjalani kegiatan sehari-hari dengan tetap bersosialisasi dan berinteraksi dengan masyarakat. Stigma dalam masyarakat muncul karena adanya perbedaan antara asumsi masyarakat (virtual social identity) dengan kenyataan (actual social identity). Hal ini benar terjadi pada keluarga pasien Coronavirus Disease 2019 dan masyarakat di Kecamatan Sungailiat. Berikut merupakan tabel bentuk stigma:

Tabel 4

Bentuk Stigma Sosial Pada Keluarga Pasien Coronavirus Disease 2019 di Kecamatan Sungailiat Kabupaten Bangka

\begin{tabular}{|c|c|c|}
\hline No. & \multicolumn{2}{|c|}{ Stigma dari Masyarakat } \\
\hline 1 & Perilaku Masyarakat & $\begin{array}{l}\text { Masyarakat membatasi Interaksi } \\
\text { dengan keluarga pasien Coronavirus } \\
\text { Disease } 2019 \text { yaitu dengan perilaku } \\
\text { berupa pengasingan, pengucilan, } \\
\text { menjauhi, dan menghindar. }\end{array}$ \\
\hline 2 & b. Actual Social Identity & $\begin{array}{l}\text { a. Masyarakat menganggap bahwa } \\
\text { keluarga pasien Coronavirus } \\
\text { Disease } 2019 \text { juga terinfeksi dan } \\
\text { masih dapat menyebarkan virus } \\
\text { Corona walaupun hasil tes } \\
\text { negatif. } \\
\text { b. Belum tentu terinfeksi. Surat } \\
\text { keterangan dokter menunjukkan } \\
\text { hasil negatif. Dan juga setelah } \\
\text { karantina kurang lebih } 10 \text { hari, }\end{array}$ \\
\hline
\end{tabular}




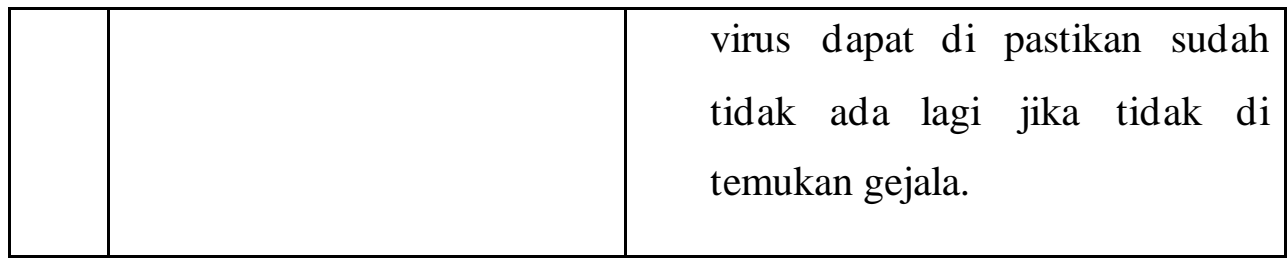

Sumber: Hasil Pengolahan Data Peneliti Tahun 2021.

Perbedaan antara asumsi dengan kenyataan yang ada didalam diri keluarga pasien Coronvirus Disease 2019 telah di ketahui dan memunculkan tindakan yang memojokkan keluarga pasien Coronavirus Disease 2019 benar adanya. Asumsi masyarakat (virtual social identity) yang diberikan masyarakat terhadap keluarga pasien Coronavirus Disease 2019 adalah masyarakat menganggap bahwa keluarga pasien Coronavirus Disease 2019 sudah pasti terinfeksi virus Corona serta masih dapat menyebarkan virus Corona walaupun sudah karantina dan hasil tes menunjukkan negatif. Sedangkan pada kenyataanya (actual social identity), keluarga pasien Coronavirus Disease 2019 belum tentu terinfeksi.

Masyarakat Kecamatan Sungailiat memberikan stigma negatif kepada keluarga pasien Coronavirus Disease 2019 karena adanya atribut yang tidak biasa didalam diri mereka. Dalam hal ini, masyarakat yang berperan dan bertindak sebagai the normals yaitu orang yang normal yang ditujukan pada orang-orang yang tidak terkena stigma. Menurut Goffman, orang-orang normal atau the normals akan menganggap bahwa orang-orang yang terkena stigma bukan bagian dari orang normal. Namun, the stigmatized atau orangorang yang terkena stigma akan menganggap diri mereka orang normal sama dengan orang lainnya dengan tetap beraktivitas seperti biasanya. Asumsi masyarakat (virtual social identity) yang diberikan masyarakat terhadap keluarga pasien Coronavirus Disease 2019 adalah masyarakat menganggap bahwa keluarga pasien Coronavirus Disease 2019 sudah pasti terinfeksi virus Corona serta masih dapat menyebarkan virus Corona walaupun sudah karantina dan hasil tes menunjukkan negatif. Sedangkan pada kenyataanya (actual social identity), keluarga pasien Coronavirus Disease 2019 belum tentu terinfeksi atau tidak terinfeksi sehingga tidak bisa menularkan virus Corona.

\section{Respon Keluarga Pasien Coronavirus Disease 2019 Terhadap Stigma Sosial}

Dengan adanya berbagai bentuk stigma yang ditujukan pada keluarga pasien Coronavirus Disease 2019 menyebabkan mereka merespon situasi tersebut dengan mengevaluasi dan memaknai dirinya sendiri apakah sesuai dengan apa yang di asumsikan 
masyarakat terhadap mereka. Di Kecamatan Sungailiat, para keluarga pasien Coronavirus Disease 2019 memberikan respon yang beragam terhadap berbagai stigma yang di tujukan kepada mereka. Respon yang di berikan tergantung bagaimana keluarga pasien Coronavirus Disease 2019 memaknai diri mereka sesuai dengan pandangan masyarakat terhadap diri mereka. Seperti yang dirasakan oleh Ibu YT, Beliau tidak setuju dengan stigma yang diberikan masyarakat kepada dirinya. Respon tidak setuju ini dituangkan dalam bentuk perasaan kecewa. Tidak hanya masyarakat yang takut atau membatasi interaksinya dengan Ibu YT tetapi teman dan keluarganya juga. Respon berupa rasa kecewa juga dirasakan oleh Ibu AF yang bahkan keluarganya yang jauh pun tak luput dari tindakan diskriminasi masyarakat yang membuat Beliau sampai menangis.

Respon berbeda di berikan oleh keluarga pasien Coronavirus Disease 2019 lainnya. Mereka setuju dengan anggapan masyarakat terhadap mereka. Seperti yang dilakukan oleh Saudari JL, Beliau setuju dengan stigma yang diberikan masyarakat kepada Beliau dan anggota keluarganya yang lain. Beliau memaknai dirinya melalui berbagai stigma yang diberikan masyarakat dengan menganggap hal tersebut merupakan hal yang wajar karena situasi sekarang dimana jumlah masyarakat yang terinfeksi virus Corona bertambah secara signifikan. Hal yang sama juga dilakukan oleh Bapak KU. Bapak KU menganggap bahwa wajar masyarakat memberikan stigma sebab masyarakat takut. Setelah keluar hasil pun Bapak KU bersosialisasi lagi dengan masyarakat. Masyarakat sebagian ada yang tidak mengetahui kalau Bapak KU merupakan salah satu keluarga pasien Coronavirus Disease 2019. Berikut merupakan tabel respon keluarga pasien Coronavirus Disease 2019:

Tabel 5

Respon Keluarga Pasien Coronavirus Disease 2019 Terhadap Stigma di Kecamatan Sungailiat Kabupaten Bangka

\begin{tabular}{|c|c|c|}
\hline No. & $\begin{array}{c}\text { Respon Keluarga Pasien Coronavirus } \\
\text { Disease } 2019\end{array}$ & Uraian \\
\hline
\end{tabular}




\begin{tabular}{|c|c|c|}
\hline 1 & $\begin{array}{l}\text { Tidak Setuju dengan Stigma yang di } \\
\text { Berikan Masyarakat }\end{array}$ & $\begin{array}{l}\text { Ditunjukkan dengan perasaan } \\
\text { kesal, sedih, dan kecewa. } \\
\text { Keluarga pasien Coronavirus } \\
\text { Disease } 2019 \text { tidak setuju } \\
\text { karena tidak sepantasnya } \\
\text { mereka menerima perlakuan } \\
\text { seperti itu karena mereka } \\
\text { sama seperti masyarakat } \\
\text { lainnya (the normals) yang } \\
\text { tidak terinfeksi dan tidak } \\
\text { sepatutnya untuk dijauhi. }\end{array}$ \\
\hline 2 & $\begin{array}{l}\text { Setuju dengan Stigma yang di Berikan } \\
\text { Masyarakat }\end{array}$ & $\begin{array}{l}\text { Menganggap stigma dari } \\
\text { masyarakat merupakan hal } \\
\text { yang wajar mengingat saat ini } \\
\text { penambahan kasus virus } \\
\text { Corona terus bertambah } \\
\text { secara signifikan. }\end{array}$ \\
\hline
\end{tabular}

Sumber: Hasil Pengolahan Data Peneliti Tahun 2021.

Respon atau reaksi tersebut berupa respon tidak setuju keluarga pasien Coronavirus Disease 2019 terhadap stigma dari masyarakat yang ditunjukkan dengan perasaan sedih, kesal, dan kecewa. Keluarga pasien Coronavirus Disease 2019 tidak terima dengan pandangan masyarakat terhadap mereka. Respon berbed a di berikan oleh keluarga pasien Coronavirus Disease 2019 lainnya. Mereka setuju dengan anggapan masyarakat terhadap mereka. Menganggap stigma dari masyarakat merupakan hal yang wajar mengingat saat ini penambahan kasus virus Corona terus bertambah secara signifikan.

\section{Pengelolaan Stigma Keluarga Pasien Coronavirus Disease 2019 di Kecamatan Sungailiat}

Keluarga pasien Coronavirus Disease 2019 akan melakukan pengelolaan stigma terhadap stigma yang melekat dalam diri mereka dengan melakukan hal-hal yang membuat mereka tidak menjadi lebih buruk dimata masyarakat. Keluarga pasien 
Coronavirus Disease 2019 akan melakukan pengelolaan stigma terhadap dirinya agar tetap terlihat normal di mata masyarakat (discredit stigma). Goffman menjelaskan, terdapat dua bentuk kasus dalam stigma yaitu discredit stigma dan discreditable stigma. Dalam discredit stigma, ketika seseorang di berikan stigma maka ia akan melakukan pengelolaan stigma sehingga dirinya terlihat normal. Sedangkan discreditable stigma, seseorang yang telah terstigma akan berperilaku tidak menjadi lebih buruk dari apa yang telah terjadi.

Pengelolaan stigma dapat dilakukan dengan berbagai cara agar dapat dilakukan pembentukan karakter ketika berinteraksi dengan masyarakat. Menurut Goffman di dalam dramaturgi, individu akan memainkan perannya masing-masing bak sebuah drama atau membuat orang lain percaya dengan peran yang sedang dimainkannya. Pada discredit stigma yang dialami oleh keluarga pasien Coronavirus Disease 2019 di Kecamatan Sungailiat, pada praktiknya melakukan pengelolaan stigma dengan menunjukkan kepada masyarakat bahwa mereka tidak terinfeksi dengan melakukan interaksi dengan masyarakat sehingga terlihat normal. Seperti yang dilakukan oleh Saudari JL. Sudari JL tetap menjalin komunikasi dengan masyarakat. Beliau meyakinkan masyarakat kalau Beliau negatif Coronavirus Disease 2019 dengan bermain ke rumahrumah tetangga.

Discreditable stigma yang dilakukan oleh keluarga pasien Coronavirus Disease 2019 di Kecamatan Sungailiat adalah dengan berperilaku sesuai dengan apa yang di inginkan masyarakat agar dapat di anggap normal oleh masyarakat. Seperti yang dilakukan oleh Ibu MN. Ibu MN berperilaku sesuai dengan apa yang diinginkan masyarakat. Masyarakat membatasi interaksi dengan keluarga pasien Coronavirus Disease 2019 sehingga mereka menuruti apa yang diinginkan masyarakat dengan tetap berada dirumah sehingga tidak menjadi lebih buruk dari apa yang telah terjadi. Ibu MN memilih dirumah saja daripada dijauhi oleh masyarakat. Beliau juga membatasi diri jika bertemu dengan masyarakat yang masih menjauhi dirinya dengan cara menghindarinya.

Hal yang sama juga dilakukan oleh Ibu AF. Ibu AF menyatakan bahwa beliau dan anggota keluarganya yang lain tidak keluar rumah karena menjaga masyarakat lain yang berinteraksi dengan mereka walaupun mereka negatif. Beliau juga merasa tidak enak hati kepada masyarakat jika keluar rumah. Berikut merupakan tabel pengelolaan stigma keluarga pasien Coronavirus Disease 2019: 
Tabel 6

Pengelolaan Stigma Keluarga Pasien Coronavirus Disease 2019 di Kecamatan Sungailiat Kabupaten Bangka

\begin{tabular}{|c|l|l|}
\hline No. & \multicolumn{2}{|c|}{ Perilaku Keluarga Pasien Coronavirus Disease 2019} \\
\hline 1 & Discredit Stigma & $\begin{array}{l}\text { Berinteraksi dengan masyarakat } \\
\text { sehingga tetap dianggap normal sama } \\
\text { seperti masyarakat lainnya. }\end{array}$ \\
\hline 2 & Discreditable Stigma & $\begin{array}{l}\text { Berperilaku sesuai dengan apa yang di } \\
\text { inginkan masyarakat agar dapat } \\
\text { terlihat normal sama seperti } \\
\text { masyarakat lainnya yaitu tetap berada } \\
\text { di rumah dengan melakukan karantina } \\
\text { mandiri seperti berjemur. }\end{array}$ \\
\hline
\end{tabular}

Sumber: Hasil Pengolahan Data Peneliti Tahun 2021.

Keluarga pasien Coronavirus Disease 2019 akan melakukan pengelolaan stigma dalam discredit stigma yaitu dengan berinteraksi dengan masyarakat sehingga tetap dianggap normal sama seperti masyarakat lainnya. Hal ini dilakukan oleh keluarga pasien Coronavirus Disease 2019 agar mereka tetap diterima didalam masyarakat. Seperti yang dijelaskan Goffman bahwa dalam discredit stigma, individu akan melakukan pengelolaan stigma terhadap dirinya sehingga dapat terlihat normal dalam masyarakat.

Discreditable stigma yang dilakukan oleh keluarga pasien Coronavirus Disease 2019 di Kecamatan Sungailiat adalah dengan berperilaku sesuai dengan apa yang di inginkan masyarakat agar dapat di anggap normal oleh masyarakat. Pengelolaan stigma yang dilakukan oleh keluarga pasien Coronavirus Disease 2019 membentuk pola interaksi yang menurut mereka nyaman. Pengelolaan stigma yang dilakukan oleh keluarga pasien Coronavirus Disease 2019 ini juga membuat mereka tidak berperilaku lebih buruk dari stigma yang telah di berikan dengan menuruti keinginan masyarakat yaitu tetap berada di rumah dengan melakukan karantina mandiri seperti berjemur serta melakukan interaksi kepada masyarakat sehingga mereka terlihat normal. 


\section{KESIMPULAN}

Stigma yang ada didalam masyarakat menimbulkan prasangka dan diskriminasi terhadap orang-orang yang terlibat didalam Coronavirus Disease 2019 seperti orangorang yang terlibat dalam kasus kontak erat, kasus suspek, kasus konfirmasi tanpa gejala, dan kasus terkonfirmasi. Selain ditujukan pada pasien Coronavirus Disease 2019, stigma juga ditujukan kepada keluarga mereka seperti yang terjadi di Kepulauan Bangka Belitung tepatnya di Kecamatan Sungailiat, Kabupaten Bangka. Bentuk stigma sosial pada keluarga pasien Coronavirus Disease 2019 di Kecamatan Sungailiat adalah perilaku pengasingan, pengucilan, menjauhi, menghindari, dan menjaga jarak karena adanya rasa takut, waspada, dan kurangnya kerahasiaan. Respon keluarga pasien Coronavirus Disease 2019 terhadap stigma adalah ada yang setuju dengan pandangan masyarakat dan ada pula yang tidak menyetujui. Pengelolaan stigma yang dilakukan keluarga pasien Coronavirus Disease 2019 adalah dengan menuruti keinginan masyarakat membatasi diri bertemu masyarakat dan membentuk pola interaksi yang menurut mereka nyaman dengan tetap melakukan interaksi kepada masyarakat sehingga mereka terlihat normal.

Masyarakat harus mengurangi stigma mereka karena memberikan dampak negatif baik secara psikologis maupun sosiologis dan dapat memberikan bantuan berupa dukungan agar keluarga pasien Coronavirus Disease 2019 tidak merasa tertekan dan dapat bebas beraktivitas dengan normal tanpa tindakan diskriminasi dari masyarakat. Untuk pemerintah, diharapkan dapat memberikan sosialisasi dan edukasi berkala kepada masyarakat agar masyarakat mendapat pemahaman tentang virus Corona. 


\section{DAFTAR PUSTAKA}

\section{Kutipan Buku:}

Afrizal. (2016). Metode Penelitian Kualitatif: Sebuah Upaya Mendukung Penggunaan Penelitian Kualitatif dalam Berbagai Disiplin Ilmu. Jakarta: PT Rajawali Pers.

Hanurawan, Fattah. (2019). Psikologi Sosial Suatu Pengantar. Bandung: Remaja Rosdakarya.

Mahmudah, Siti. (2011). Psikologi Sosial: Teori Dan Model Penelitian. Malang: UINMaliki Press.

Martono, Nanang. (2012). Sosiologi Perubahan Sosial: Perspektif Klasik, Modern, Posmodern, Dan Poskolonial (Sampel Halaman). Jakarta: RajaGrafindo Persada.

Sarwono, Sarlito Wirawan. (2018). Psikologi Sosial (Edisi Kedua). Jakarta: Salemba Humanika.

\section{Kutipan Jurnal dan Skripsi:}

Ardianti, Anis. (2017). Stigma Pada Masyarakat “Kampung Gila ” di Desa Paringan Kecamatan Jenangan Kabupaten Ponorogo. S1 Sosiologi FISIP Universitas Airlangga, 1-27.

Falidah. (2020). Hapus Deskriminasi Sebagai Upaya Melawan Stigma Corona Virus Disease (COVID-19). Universitas Negeri Yogyakarta. 2017(1), 1-9.

Novanto, Adrian Bayu. (2017). Stigmatisasi Masyarakat Pada Kelompok Tunawisma (Studi Pada Masyarakat Di Kelurahan Kasin-Kecamatan Klojen-Kota Malang). Universitas Brawijaya.

Santoso, Danar Dwi. (2016). Stigmatisasi Orang Tua Tunggal Perempuan di Masyarakat (Studi pada Masyarakat Pedukuhan Dongkelan Kelurahan Panggunharjo Kecamatan Sewon Kabupaten Bantul). Yogyakarta: UIN SUKA. 
Susanto, Happy. (2016). Konsep Paradigma Ilmu-ilmu Sosial dan Relevansinya bagi Perkembangan Pengetahuan. Muaddib: Studi Kependidikan Dan Keislaman, 4(2). http://doi.org/10.24269/muaddib.v4i2.119

Varamitha, Sukmawati., Akbar, Sukma Noor., \& Erlyani, Neka. (2014). Stigma Sosial Pada Keluarga Miskin Dari Pasien Gangguan Jiwa. 1(3), 106-114.

\section{Kutipan Website:}

Pusat Informasi COVID-19 Kabupaten Bangka. 2021. Peta Penanganan COVID-19 Per Kecamatan. https://covid19.bangka.go.id./ 